\title{
Threat Perception, Policy Diffusion, and the Logic of Terrorist Group Designation
}

\section{Mirna El Masri \& Brian J. Phillips}

To cite this article: Mirna El Masri \& Brian J. Phillips (2021): Threat Perception, Policy Diffusion, and the Logic of Terrorist Group Designation, Studies in Conflict \& Terrorism, DOI: 10.1080/1057610X.2021.2011711

To link to this article: https://doi.org/10.1080/1057610X.2021.2011711

\section{(c) 2021 The Author(s). Published with license by Taylor \& Francis Group, LLC.}

\section{曲 Published online: 13 Dec 2021.}

Submit your article to this journal $\pi$

Llll Article views: 684

Q View related articles $\sqsubset$

View Crossmark data $\nearrow$ 


\title{
Threat Perception, Policy Diffusion, and the Logic of Terrorist Group Designation
}

\author{
Mirna El Masria,b and Brian J. Phillips, ${ }^{c, d}$ (ID \\ aSchool of Social Sciences, University of Mannheim, Mannheim, Germany; ${ }^{b}$ German Institute for Global \\ and Area Studies (GIGA), Hamburg, Germany; 'Department of Government, University of Essex, \\ Colchester, United Kingdom; ${ }^{d}$ Center for Research and Teaching in Economics (CIDE), Mexico City, \\ Mexico
}

\begin{abstract}
Many governments maintain lists of terrorist groups, imposing sanctions on designated organizations. However, the logic behind designation remains unclear. Furthermore, most studies focus on Western countries. This paper develops arguments for why attack attributes, group attributes, and policy diffusion might explain proscription. Empirically, we examine hundreds of militant organizations to see which are listed by the European Union, India, Pakistan, Russia, the United Kingdom, or the United States. Generally, designation does not seem to be driven by target or attack severity. It often results from diffusion: most countries follow the United States. Islamist group motivation is also an important factor.
\end{abstract}

\section{ARTICLE HISTORY}

Received 8 April 2021

Accepted 17 November 2021

Governments around the world have implemented so-called terrorist designation lists, which label groups as terrorists for counter-terrorism purposes. However, there is no consensus about the designated organizations, and lists vary considerably. Even though the popularity of designation lists is growing, the "terrorist" label is highly debated and ambiguous, not only among governments and policymakers, but also among academics. ${ }^{2}$ Designation, also called proscription, is important to understand because governments expend resources putting groups on lists to "name and shame" them, and subject them to formal sanctions. There is growing evidence that the lists have serious consequences - intended and unintended. ${ }^{3}$ Less is known about why some groups end up designated as terrorists, while others do not. This is a substantial gap in the literature, since designation apparently has important effects.

Most studies of terrorist group designation analyze Western countries, such as the United States, the United Kingdom, or the European Union. ${ }^{4}$ Focusing only on determinants affecting the designation of terrorist groups by Western governments restricts the studies to Western threat perceptions. Other types of countries have created terrorist lists, but it remains unclear if the logic of listing differs for these countries compared to the often-studied Western states. Moreover, the one study to explicitly compare terrorist lists and their determinants quantitatively includes a limited number of measures of terrorist group attributes, and only examined groups through $2008 .^{5}$ 
What determines the designation of organizations as terrorists? Drawing on insights of previous studies on the designation, as well as research on militant groups and counterterrorism, we contribute to the literature by considering several theoretical explanations that potentially lead to designation. Empirically, we focus not only on the United States, the United Kingdom, and the European Union, but also on several non-Western governments: Russia, Pakistan, and India. ${ }^{6}$ Therefore, we conduct the most comprehensive quantitative analysis of terrorist group lists. Moreover, we look at the quality of attacks as opposed to only the quantity of attacks, and take into consideration that one state's designation decisions might affect other states' decisions.

In what follows, we first define "terrorist groups" and "designation" and review existing studies on the determinants of designation. In the next section, we argue that the designation of terrorist groups is not only affected by the perceived threat of the organization, in terms of the severity of attack methods and target types, but also by U.S.-led policy diffusion and Islamist ideology. After developing our arguments, we test them empirically in the fourth section with longitudinal data on hundreds terrorist groups from 1970 to 2016. In this analysis, we do not only examine designated groups, but also the broader universe of potentially listable groups.

We find that even though governments claim that threats are the primary purpose of their designation mechanism, terrorist designation is not primarily driven by target or attack method severity. Even suicide attacks are not robustly associated with proscription. In contrast, the analysis demonstrates that there is some diffusion among Western governments, providing support for the argument of U.S. policy diffusion. There is evidence of several states influencing designation by others, but the U.S. list is the most influential. Moreover, we find that Islamist groups are especially likely to be designated, even after we control for many other group attributes. We conclude with a discussion of the implications of the findings and directions for future research.

\section{Literature: Designation in a Global Perspective}

A growing line of research looks at terrorist designation or proscription. Much of the work looks at consequences of designation, such as whether it achieves the desired goals of reducing terrorism or otherwise constraining violent groups. Several studies find that listing seems to reduce the terrorism of only specific kinds of groups, such as those that are younger, ${ }^{7}$ those that depend on donations, ${ }^{8}$ or those that operate in U.S.-allied countries. ${ }^{9}$ Some research also looks at unintended consequences of designation, such as limiting freedom of expression or organization, obstructing peace processes, or hindering economic development. ${ }^{10}$ However, to fully understand proscription and its effects, it is important to understand why some groups get listed at all. In this section we discuss the concepts of terrorist groups and designation, and in the following sub-section we review some of the research on how terrorist group lists are constructed.

Debates continue about the definition of "terrorist groups,"11 and to what extent terrorism is distinct from other forms of political violence. Many analysts use an inclusive definition, stating for example that a terrorist group is a "subnational political organization that uses terrorism." ${ }^{2}$ We adopt this definition as well. Other authors 
specify that terrorist groups are organizations that primarily use terrorism, or that they do not hold territory, or that primarily target civilians. ${ }^{13}$ For the purpose of this paper, we refer to the first definition because it is a broad enough understanding to include the many groups likely to be designated by governments. It is a definition used implicitly or explicitly by a variety of studies. ${ }^{14}$ Additionally, governments seem to use such a notion of "terrorist groups," as they do not limit their lists to sub-categories of groups such as those that that do not hold territory.

A designation demonstrates a legal procedure in which the support or the existence of identified organizations or individuals is being constrained by authoritative actors, such as governments. ${ }^{15}$ Governments designate an organization if they believe it uses terrorism and is a significant threat to the state or its interests. While a designation itself serves as a signal of the negation of a group, it also seeks to restrain extremist activities. ${ }^{16}$ The suppression of groups results in the application of criminal offenses, such as the constraint of support for listed groups and/or the criminalization of a participation in a specific group, and is thus the political embodiment of blacklisting. ${ }^{17}$ The terms proscribing, listing, blacklisting, outlawing, and banning orders are regularly used as synonyms. ${ }^{18}$ Despite being employed widely, terrorism designation is highly inconsistent across the globe.

\section{Research on the Designation Process}

Some relevant literature on terrorist group designation is the work on designation effectiveness. ${ }^{19}$ Other work looks at the process behind how specifically a government designates a group. ${ }^{20}$ While helpful for understanding aspects of proscription, this research does not explain general patterns internationally in designation. This, most likely, is due to fact that attempts to designate identified terrorist organizations are limited to post-9/11 counterterrorism mechanisms ${ }^{21}$ and, despite that, inconsistently applied across the globe. Moreover, designation-capabilities deserve more attention given that their effectiveness and importance in the fight against terrorism continues to be debated. ${ }^{22}$

Some research draws attention on current designating governments which are impacted by conflicts of the twentieth century, focusing on the United Kingdom in particular. ${ }^{23}$ Other research examines how designation-efforts represent a vague process of decision-making and are generally based on superficial assumptions which end up in entailing violations of human rights. ${ }^{24}$ Following that, narratives around violations of human rights are demonstrated by scholars who analyzed the designation process of Canada and Australia respectively. ${ }^{25}$ Their findings examine extremist narratives of Western anti-Muslim racism, in which Muslim communities are unfairly targeted within contemporary counterterrorism initiatives and that designation is "indiscriminately aimed at Muslims rather than violence." 26 This idea is consistent with findings by Beck and Miner, who analyze factors influencing the designation of groups by three Western designating governments: the United States, the United Kingdom, and the European Union. ${ }^{27}$ As for Western narratives in the designation process, Nadarajah emphasizes how the consideration of only Western designating countries might restrict determinants of factors influencing a designation to common Western "liberal peace logics." 28 
This might restrict the determinants to common Western designation factors and thus undermine other possible aspects influencing a designation. Additionally, it has been argued that the U.S. list in particular is based in part on political factors, for example the desire to appease foreign allies, instead of solely concerns about threats a group might pose to the United States. ${ }^{29}$

Western countries have been influential in the creation of terrorist lists, and the diffusion of these ideas to other countries. Stampnitzky argues that the modern understanding of "terrorism" was created by a small number of experts and officials in the 1970s, mostly in the United States. ${ }^{30}$ This is in part because the West at that time was being targeted by airline hijackings, attacks at the Olympics, and other high-profile violence that came to be understood as terrorism. Western countries were among the first of this era to develop proscription regimes, sometimes repeating proscription practices they had used as colonial powers early in the twentieth century. ${ }^{31}$ As a result, Western policies are important to understand, even if the idea of terrorism proscription is now a global phenomenon.

Beyond arguments specific to the West, others draw upon more general ideas about domestic politics or traditional international relations. Politicization happens in a variety of countries. ${ }^{32}$ Designating governments reflect how states construct specific entities as "security threats in order to allow the state institutions to exercise their sovereign power to carry out extraordinary measures." 33 Other research explores how the designation of a terrorist group is affected by symbols by the powerful and manipulation of language, ${ }^{34}$ and how governments might copy one another's designation lists. ${ }^{35}$ Hence, a designation is a political and symbolic act, as well as an act of securitization, in which the designation of a terrorist organization might be influenced by the connection between a country and the international community. ${ }^{36}$

Some previous studies of terrorist group lists consider these factors, but usually only focusing on one single designating government. ${ }^{37}$ Other studies examine multiple governments and explore factors like the quantity of attacks of militant groups, but do not consider the quality of attacks. ${ }^{38}$ Additional shortcomings in the literature, as noted above, include overlooking designation in non-Western countries, with few exceptions.

Given that governmental designation lists are inconsistently applied across the globe, the question about what makes a government designate organizations as terrorists and why remains open. The following section seeks to address this by presenting five hypotheses that suggest: (1) the target types of terrorist groups influence a governmental designation, and (2) the attack method influences the likelihood of being designated. However, targets and attacks do not exist in vacuum. We also argue that (3) the United States influences designation decision of other states, (4) Islamist group ideology is associated with prescription, and (5) affiliates of al-Qaeda or Islamic State are especially likely to be designated.

\section{On Threat Perception and U.S. Policy Diffusion}

States are likely to designate an organization as a terrorist group if they perceive threats from the organization in question. This section presents theoretical pathways linking attack and target types, policy diffusion, and Islamist ideology to terrorist proscription. Before doing so, we draw on Beck and Miner's logic of legal classifications of terrorism 
and the construction of perceived threat and deviance. Legal classifications of terrorism stem from a state's interpretation of events and their presumed causes, ${ }^{39}$ as well as the "actual assessment of danger" ${ }^{40}$ Interestingly, all six governmental designation lists have one thing in common in their regulations about designating terrorists: they all designate groups if they perceive threats from the organization in question. Our assertion is thus that the designation of terrorists is caused by a state's perceived threat of an organization, where specific attack methods and target types of groups are more likely to be seen as a threat than others.

Beck and Miner also suggest that governments' notions of terrorism are affected by other actors, such as the media and other governments. ${ }^{41}$ A court decision by E.U. leaders in 2006 to designate the Liberation Tigers of Tamil Eelam (LTTE), for instance, had been based on "imputations derived from the press and the Internet" rather than on direct investigation of the organization's actions. ${ }^{42}$ Conrad and Greene argue that terrorist organizations receive short-term benefits from the use of innovative attack types and by attacking more severe targets, given that these will influence the media, and ultimately, the general public and government. ${ }^{43}$

Furthermore, terrorist attacks need to pass an "emotional threshold" for the media to cover the event, and since homicide - in particular, one caused by a terrorist attack - is a relatively rare event, it is generally "newsworthy" ${ }^{44}$ The same logic can be applied to the designation process of terrorists. Terrorist organizations need to pass an emotional threshold by employing severe attack methods and targeting more shocking targets in order to influence governments' perceptions and thus a designation. There is wide variation in the severity of terrorist attacks. Some attacks have greater psychological impacts, garner greater media coverage, and are likely to influence a wider audience than others. Similarly, research on the consequences of terrorism finds that more severe events yield a much stronger impact than less severe events. ${ }^{45}$ Lemyre et al. find that with terrorism, perceptions of a threat itself can lead to adverse effects on psychological well-being, the economy, or political decision making. ${ }^{46}$

In a nutshell, threats do indeed affect public concern and ultimately have an impact on political decision making in the form of designating groups as terrorists. Moreover, given that severe threats achieve a greater impact than less severe threats, it is more likely for organizations employing severe threats to be designated as terrorists by governments. We follow Conrad and Greene who suggest that severity of terrorism can be determined by the targets as well as the tactics of the organization in question. ${ }^{47}$ We discuss the two categories in turn and consider implications for designation.

\section{Designation as a Result of Target Types}

Chermak and Gruenewald describe an "emotional threshold" that must be crossed by terrorist violence in order for it to gain substantial media coverage. ${ }^{48}$ Similarly, it seems likely that terrorist organizations need to pass such a threshold to draw the attention of governments, perhaps leading to a designation. ${ }^{49}$ Attacking especially "shocking" targets can make violence especially terrifying. Several existing studies point out that targets are salient markers of terrorism. ${ }^{50}$ This section develops the logic underlying the claim that highly severe or "shocking" target types affect the likelihood of an organization being designated as a terrorist. 
Existing studies suggest that terrorist attacks against civilians, ${ }^{51}$ nongovernmental organizations (NGOs), and the media demonstrate the most extreme or severe level of terrorist target choice. ${ }^{52}$ However, attacks on civilians are "much more costly than attacks on official targets in terms of loss of popular support and legitimacy", 53 which makes them more likely to lead to a designation. For example, the United States designated Boko Haram, as well as its offshoot Ansaru, as terrorist organizations in November 2013, due to "thousands of deaths in the northeast and central Nigeria over the last several years including targeted killings of civilians." ${ }^{4}$ Analogously, the United States designated Hamas after it conducted several attacks against Israeli civilians in the 1990s. ${ }^{55}$ We thus argue that targeting civilians demonstrates the highest severity level, given that attacks against these targets are very costly and generate a possible backlash effect.

Polo notes that different types of targets carry a different "valence" for both terrorists as well as their audience. ${ }^{56}$ Consistent with this, Conrad and Greene argue that attacks against governmental targets and infrastructure demonstrate that terrorists do actually have the capability to impose costs on the government, but choose to generally minimize the chances of harming civilians to avoid a potential backlash effect. ${ }^{57}$ Moreover, governmental targets such as the police or the military, as well as key infrastructures are often perceived as more "legitimate" targets. Hence, targeting governmental officials is less severe than targeting civilians. At a lower level of severity, damaging utilities such as oil pipelines and power lines is disruptive for the government, but not as shocking as other types of targets. A possible backlash effect, associated with the targeting of civilians or other more sensitive target types, is avoided. Attacks on less-severe targets such as pipelines should be less likely to cause a group to be blacklisted by a government. In sum, we thus argue that the severer the target, which is attacked by a terrorist organization, the higher the likelihood of designating the organization in question. This suggests the following hypothesis:

$\mathrm{H}_{1}$ : An organization that attacks more severe targets is more likely to be designated as a terrorist group.

\section{Designation as a Result of Attack Methods}

Beyond target types, there are specific categories of Attack methods that are likely to signal their perpetrators as especially threatening. While research on terrorism has tended to focus on the quantity of attacks, others distinguish between the quantity and the quality of attack methods and highlight the importance of the severity of such methods. ${ }^{58}$ This section illustrates how highly severe or "shocking" attack methods bear a higher possibility of influencing a designation.

Conrad and Greene argue that simply increasing the amount of violence is not the only (or even a useful) way to distinguish an organization's threat. ${ }^{59}$ They demonstrate that raw counts of the number of terrorist attacks do not capture the fact that the quality of the attacks in terms of severity varies widely. We can similarly expect different severity levels when considering the quality and thus the different methods of attacks terrorists use. Given that terrorists consider the "shock value" of not only their targets but also their attack methods, it is reasonable to believe that a high "shock value" may be one way to influence a designation. 
Some studies that have considered the severity of attack methods have focused almost exclusively on the use of suicide terrorism. ${ }^{60}$ Bloom argues that one reason suicide terrorism is so shocking is that it "eras[es] the imagined barriers between combatants and non-combatants, terrorists and innocent civilians." ${ }^{61}$ This severe method gets groups noticed and designated as terrorists. For instance, the leftist Revolutionary People's Liberation Front (DHKP/C) in Turkey has repeatedly used suicide attacks and is designated as a terrorist organization by multiple countries. As Beck and Miner point out, other comparable groups using terrorism in the region, such as the National Liberation Front of Corsica, remain un-designated. ${ }^{62}$

Beyond suicide attacks, bombings in general are seen as extreme or severe attack methods. ${ }^{63}$ In some ways, bombings represent an ideal type of terrorism. One scholar argues that bombings are the "most likely terrorist method of inflicting mass casualties." 64 Bombings can reach a scale of injuring or killing a high number of civilian targets, such as the 1998 car bombing of the U.S. embassy in Nairobi, which killed hundreds of civilians and injured over $4,000 .{ }^{65}$ As a result, suicide attacks and bombings are considered at the highest severity level, since they have the capacity for great lethality, and are more indiscriminate compared to other attack methods.

Other attack types, such as hijacking, are less severe. Even though some scholars note that hijacking and hostage takings draw considerable media coverage, ${ }^{66}$ other literature suggests that the most-covered terrorist events are those resulting in actual death or injury of the targets. ${ }^{67}$ Moreover, many kidnappings are not covered by the news, and are frequently resolved in private instead. ${ }^{68}$ As previously argued, attacks against infrastructure can be considered at the lowest severity-level. This is comparable to other attack types, such as unarmed assaults. It seems reasonable that attacks on the lower end of the severity scale would be less likely to cause a group to be designated as a terrorist organization. Overall, this leads to the following hypothesis:

$\mathrm{H}_{2}$ : An organization that uses highly severe attack methods is more likely to be designated as a terrorist group.

\section{Designation as a Result of U.S. Policy Diffusion}

Policy choices of one country are often shaped by the previous choices of others. Scholars have shown that the adoption of policies has varied as anti-money-laundering rules to renewable energy use occurs through diffusion. ${ }^{69}$ Policy diffusion can happen through a number of different mechanisms, including benign or positive processes like learning. ${ }^{70}$ Some countries express their general desire to cooperate on counterterrorism, such as the U.K. Home Office stating among its proscription criteria "the need to support other members of the international community in the global fight against terrorism." ${ }^{71}$ Another common explanation for policy diffusion focuses on a less benevolent mechanism: coercion. Coercion can be performed by governments as they manipulate economic costs and benefits, use physical force, or the monopolize information. ${ }^{72}$ In the case of terrorism designation, the preferences of the United States, for instance, may shape the policies in countries reliant on its foreign direct investment, aid, or security by offering more of these, or threatening to withhold.

Coercion also operates through another mechanism: hegemony. Dominant governments (hegemons), such as the United States, can influence the policy of other countries 
without exerting physical force or directly changing costs or benefits. ${ }^{73}$ The event of 9/11 and the American War on Terror, for example, is not only credited to be a cover for global strategic interests and preserving the U.S. hegemony, ${ }^{74}$ but has also marked a transformation in the international designation process, as the United Nations urged member states in Security Council Resolution 1373 to implement counterterrorism measures. ${ }^{75}$ This event marks an important time in the history of designation, given that several U.S.-allied governments followed the U.S. designation mechanism and established their own designation lists shortly afterwards. ${ }^{76}$ In turn, we argue, the U.S. designation of an organization as a terrorist influences the designation processes of other countries. Such behavior is especially likely for countries already following the U.S. foreign policy on counterterrorism. ${ }^{77}$ This could be at least in part because international cooperation is essential for a designation to have meaningful consequences. ${ }^{78}$ However, generally, most countries should be likely to follow the United States in its designation decisions due to its status as a global power and arguably the hegemon. ${ }^{79}$ This is consistent with qualitative research concluding that the United States is a "trendsetter" regarding proscription. ${ }^{80}$

Sometimes the United States directly advocates for other states to follow its terrorist designation patterns. The U.S. State Department, on the FTO web-page, indicates that it hopes listing "signals to other governments our concern about named organizations." 1 More directly, some U.S. officials have lobbied the European Union to list Hezbollah as a terrorist organization. ${ }^{82}$ U.S. lobbying has led to the proscription of various groups. For example, the United States proscribed the Tamil Tigers in 1997, but Canada resisted until 2006. ${ }^{83}$ U.S. pressure was "critical" for encouraging Canada to eventually list the group. ${ }^{84}$ Overall, through various mechanisms, U.S. listing decisions are likely to affect the subsequent listing decisions of other governments.

Hence, the third hypothesis is as follows:

$\mathrm{H}_{3}$ : An organization that has been designated as a terrorist group by the United States is more likely to be designated as such by other governments in subsequent years.

\section{Designating Islamist Groups}

Several allied governments followed the U.S. designation process by implementing their own designation lists shortly afterwards. The U.S. Foreign Terrorist Organization (FTO) list contains a large number of groups which claim an Islamist ideology. This is due to the event of $9 / 11$ and the subsequent U.S. War on Terror, but most broadly due to the "fourth wave" of religious terrorism which replaced the "third wave" of leftist attacks that had peaked the Cold War. ${ }^{85}$ Moreover, while leftist terrorism in the third wave was mainly of a Marxist ideology, in which a national liberation framework was used to make appeals to the middle and lower classes, "Islamist terrorism is seen as making a broader multi-class appeals, using more lethal tactics justified in religious terms, and is more organizationally consolidated." ${ }^{66}$ Given that many governments established their designation lists around the beginning of the fourth wave of terrorism, we argue that an Islamist ideology influences the listing process of designating governments. This ideology is considered to be a higher threat to Western society than leftist or ethnonationalist motivations. For example, the United States designated the 
Islamist group Jaysh Rijal al-Tariq al Naqshabandi (JRTN) as a terrorist group on the FTO list in 2015. However, the similarly active group which also targets civilians, the United Liberation Front of Asom (ULFA), remains undesignated by the United States. Thus:

$\mathrm{H}_{4}$ : An organization with an Islamist ideology is more likely to be designated as a terrorist group.

While an Islamist ideology generally is likely to earn a militant group proscription, much of the Islamist violence affecting countries with terrorist lists comes from specific networks. Al-Qaida perpetrated out the massive Sept. 11, 2001, attack, which in many ways spurred the modern terrorism-sanctioning regime. The organization and its affiliates continued to launch major attacks around the world. In the 2010s, the so-called Islamic State developed its own network of affiliates, which were seen as substantial threats by many countries. As a result, we argue that any group affiliated with either al-Qaida or the Islamic State should be seen as especially threatening, and therefore more likely than even other Islamist groups to be added to a "terrorist" list.

$\mathrm{H}_{5}$ : An organization affiliated with either al-Qaida or the Islamic State is more likely to be designated as a terrorist group.

\section{Data and Research Design}

The analysis uses two primary data sources to assess the hypotheses: the Extended Data on Terrorist Groups (EDTG) and the Global Terrorism Database (GTD). ${ }^{87}$ We use these two data sources because they are, to our knowledge, the most comprehensive publicly available data sources on militant groups that use terrorism, and terrorist attacks, respectively. ${ }^{88}$ The EDTG already includes some GTD-based variables, but we bring in additional information from the GTD for our attack severity and attack methods variables. The unit of analysis is group-year, and the data includes 566 militant organizations for the period 1970-2016. Models have fewer groups, between 272 and 470, due to missing information on some variables and the years examined in each analysis. We combined this group-year data with data from six countries' terrorist group lists, as discussed below. The main variables for analyzing the above hypotheses are measures of designation status as the dependent variable, along with many independent variables.

\section{Dependent Variables: Terrorist Designation}

To measure terrorist designation, we compile proscription information from six lists: the primary terrorist lists of the United States, the United Kingdom, the European Union, Russia, Pakistan, and India. We choose this sample to have a mix of Western and non-Western countries. It includes the three Western lists included in Beck and Miner's path-breaking study - the first systematic comparative study of more than two lists - and adds three prominent non-Western countries that make interesting contrasts. Europe is over-represented, as are democratic countries. However, it is difficult to get reliable information on the lists of non-democratic countries, especially on how the 
lists have changed over time. Future research would benefit from analyzing additional lists, but this sample is larger than most analyses of terrorist lists to date, and we think it is an interesting mix of types of states from various regions.

There is a global divergence around which organizations are "terrorist groups." The Appendix provides a more detailed explanation. This divergence can be even observed among allied countries with extensive records of cooperation regarding counterterrorism and beyond. Here, the United States holds the most prominent designation list, the FTO List, which has its origins in 1997 and currently contains 69 organizations. ${ }^{89}$ However, the U.S. designation list differs from the lists of other governments by only designating foreign terrorist groups. Meanwhile, the United Kingdom presently includes 96 domestic and international organizations on its list, established by the Home Secretary in 2001.90 The European Union designates terrorists as part of its response against terrorism after the attacks of 11 September 2001 under two separate lists: 1. one list including all non-E.U. persons and entities with currently 21 designated groups, ${ }^{91}$ 2. the other list including all E.U. (and non-E.U.) persons and entities. ${ }^{92}$ As for the following analysis, we use the second list which includes all E.U. and non-E.U. entities. ${ }^{93}$ Currently, 47 groups are designated on their list, following the UNSC resolution $1373 .{ }^{94}$

As for non-Western designating governments, Russia officially designates groups as terrorists since 2003 on their Federal United list of Terrorist Organizations, with currently 31 organizations designated by the National Anti-Terrorism Committee. ${ }^{95}$ In Pakistan, the Ministry of Interior has designated organizations as terrorists since 1997, and currently lists 73 organizations. ${ }^{96}$ India’s Ministry of Home Affairs has a designation list under the Unlawful Activities (Prevention) Act, which originated in 1963 and currently designated 40 organizations. ${ }^{97}$ Overall, there are some similarities in the process of designation. The listing governments have similar definitions of terrorism and mostly have similar purposes of the designation lists.

We match our data on militant groups to the six national terrorist lists to create six dichotomous dependent variables measuring whether a group appeared on each list during the particular year. Each group is coded " 1 " for years they are designated, and "0" for all other years. Not all listed organizations appear in the EDTG and GTD, some appear under multiple names, and ending the sample in 2016 excludes some designated terrorist groups. ${ }^{98}$ Moreover, removing cases with missing data to maintain comparability across the samples results in the following number of designated terrorist groups included in our analysis: 71 groups on the U.S. list; 58 groups on the U.K. list; 33 groups on the E.U. list; 19 groups on the Russian list; 33 groups on the Pakistani list; and 36 groups on the Indian list. These lists of course overlap - many groups are on multiple lists. Additionally, these are total numbers, including groups that were later de-listed.

With the measures of each country's list, we make our primary dependent variables: All countries and Any countries. All countries is an additive ordinal dependent variable (0-6), which is the total number of countries designating a group. Any country is a dichotomous variable coded " 1 " if the group appears on any country's list that year. These are our primary dependent variables because we are interested in designation overall - by either more countries, or by any country - instead of the designation patterns of one single country. These dependent variables allow us to draw inferences about patterns across these various and distinct states. 
In addition to models with All countries and Any country, we include models where the dependent variable is designation by one of the six designators. This is necessary to test Hypothesis 3, about policy diffusion across countries. It also will illuminate differences across the designation patterns of different countries, as they are likely to have distinct priorities when designating groups as terrorists.

\section{Key Explanatory Variables}

To assess whether the severity of target selection and attack methods affects the designation of groups as terrorists, we follow the coding scheme of Conrad and Greene, in which a set of ordinal measures is proposed to capture the severity level or "shock value" of terrorist attacks. This results in two ordinal independent variables, Target type and Attack method.

Regarding Target type used to measure Hypothesis 1, the GTD identifies 22 target categories. Conrad and Green classify attacks as low, medium, or high severity. Target type is coded " 1 " if the attack is against infrastructure targets, such as transportation, telecommunications, airports, food or water sources, or maritime infrastructure. The next level of severity is captured by a variable equaling " 2 " if an attack is against governmental personal, police, military, violent political parties, or other terrorists. The highest level of severity is " 3 " and includes attacks against all civilian targets, including tourists, private citizens, NGOs, the media, private businesses, and educational personal. These targets are more likely to be "shocking." Groups that did not carry out any attacks in the year are coded as " 0 ". 99

Regarding Hypothesis 2, about attack methods, the GTD categorizes eight types of attacks according to the method used. We again follow Conrad and Greene's coding scheme to organize these methods into three ordinal categories, creating Attack method. The lowest value equals " 1 " in attacks in categorized by an absence of human injury or low levels of violence. These include unarmed assaults and attacks against infrastructure. If the attacks involve hijackings or hostage takings, they are attack severity level "2". These are attacks which pose a threat to human life but are probably not considered as extreme as those at the next level. The highest severity-level is " 3 " and includes armed assaults, assassinations, and bombings. Group-years with no attacks that year are coded as "0". As Conrad and Greene note, the creation of this scale involves subjective decision making, but they seem like a reasonable way to rank terrorist attacks into theoretically relevant categories. ${ }^{100}$

As a complementary measure, we also include a dichotomous variable called Suicide attack, coded " 1 " if the group has a suicide attack attributed to it in the GTD during the year being analyzed. ${ }^{101}$ Suicide attacks are one of the most-analyzed and heinous types of terrorism. Including this measure will help us understand if groups might get designated for especially brutal attack varieties, instead of an increase in attack severity - for example from not severe to moderately severe - which is what the Attack method variable might indicate. Between 5 and 9 percent of the group-years are coded "1" for Suicide attack, depending on the sample used.

To capture Hypothesis 3, about U.S. policy diffusion, we use Prior [State] designation as a dichotomous variable for each government. This variable shows whether an 
organization has been listed in the previous year of designation (or 2016 if unlisted) by the other five governments considered. Thus, it captures if the designation of some governments is associated with the designation by other governments. We will have all in all six dichotomous variables, one for each government, coding whether an organization has been listed in the previous year ("1") or not ("0"). Given Hypothesis 3 , our primary focus is on U.S. policy diffusion.

To code the Islamist ideology for Hypothesis 4, we started with the dummy variable Religious from the EDTG dataset capturing whether a group is a religious fundamentalist group or not. With this, we create a new variable, called Islamist by coding all included Islamist groups manually as " 1 " and non-Islamist groups as "0". Apart from the group name itself, sources used for coding include mainly the Terrorism Research \& Analysis Consortium (TRAC) and the Mapping Militants Project. ${ }^{102}$ For Hypothesis 5, we gather data on groups that pledged allegiance to either al-Qaida or the Islamic State. This information came from sources such as the Mapping Militants Project and the Long War Journal.

\section{Control Variables: Measurements for Countries Targeted, Attacks, and Victims}

Six dichotomous variables, Attacked [State], capture whether an organization has attacked in the country of the respective designating government that year, according to the GTD. This variable is included because it seems likely that governments would designates group that have attacked in their country. One exception is Attacked U.S., which is likely to be negatively related to designation, since this country is the only one of the six that does not attack domestic organizations.

The designation of a terrorist organization might also depend on the number of attacks an organization caused. The variable Total attacks is taken from the EDTG dataset and indicates the number of total attacks that a terrorist group launched in a given year. ${ }^{103}$ We compile the cumulative number of casualties by each organization from 1970 through the year of formal designation, up until listing or the year 2016 if unlisted. The variable Total deaths (log) is also taken from the EDTG dataset and captures the total number of deaths attributed to the group in a given year. We take a natural logarithm because of the extreme scale of the variable. ${ }^{104}$ We also include one other attack-related variable. Aviation target is taken from the GTD and captures whether an organization employs aviation attacks or not. We include this because Beck and Miner find it to be an important predictor of terrorism designation by the United States. ${ }^{105}$

Finally, we include Group age and Group size, which come from the EDTG. The perseverance and strength of a terrorist group is measured by the group size as well as the age of an organization. We include these variables because it is likely that a stronger terrorist group poses a bigger threat and is thus more likely to get designated.

\section{Model Specification}

For models with the count dependent variable All countries, we use an ordinal logit, due to the count nature of the dependent variable. For all other models, we use logistic 
regression due to the dichotomous nature of the dependent variables. Standard errors are clustered on the terrorist group. We first analyze the dependent variables All countries and Any country to see the factors associated with a group being designated by multiple states or any state. After this, we analyze the country lists one at a time to see how correlates of U.S. designation, for example, compare to the correlates of designation by other countries.

\section{Empirical Analysis and Discussion}

Table 1 shows the analysis with the dependent variables All countries and Any country. These dependent variables allow us to illustrate which factors are associated with a group being designated by a higher number of countries (All countries), or a group being designated by any of the five states or the European Union (Any country). Models 1 and 3 look at all years available, 1970-2016, to include as much information as possible and help understand general trends. Models 2 and 4 only examine 2003-2016, since 2003 is the first year that all designation lists being analyzed existed. In most of the models, results are similar. Target Type is statistically insignificant in all models. Attack method is statistically insignificant in Models 1 and 3, and only marginally significant (90\% level) in Models 2 and 4. This suggests no support for Hypothesis 1, and little for Hypothesis 2.

Suicide attack is statistically significant and positively signed in Models 1 and 3, suggesting that groups that carry out suicide attacks in a year are more likely to be designated a "terrorist group" by more countries (Model 1) than groups that did not use suicide attacks, or more likely to be designated by any country (Models 3). Suicide attack is also marginally significant in Model 4. These results suggest some support for Hypothesis 2, but only in the extreme case of suicide terrorism.

Islamist is statistically significant and positively signed in all models of Table 1, suggesting that groups with Islamist ideologies are more likely to appear on more terrorist group lists than groups with other kinds of ideologies. This suggests support for Hypothesis 4. AQ affiliate and IS affiliate are also robustly significant and positively signed in all models. This suggests groups in either global network are more likely to appear on terrorist lists, consistent with Hypothesis 5. It is noteworthy that the Islamist variable remains significant in the presence of these two measures. Even after taking into consideration the al-Qaeda and IS networks, a group with an Islamist ideology is more likely than a non-Islamist group to be proscribed as a terrorist group.

Regarding control variables, results are largely in line with expectations. The coefficients on Attacked U.S. are consistently negatively signed and statistically significant. This makes sense because the United States only designates foreign groups as terrorists, and such groups are less likely to have attacked in the United States. Other countries are also unlikely to designate groups that attack in the United States, since those are mostly U.S. domestic organizations, unlikely to threaten other countries. Attacked U.K. and Attacked India are significant and positive in all models, suggesting groups that attack these countries are likely to be designated by more countries (Models 1 and 2) or any country (Models 3 and 4) than groups that do not. The measure of attacking in Pakistan is similarly positively signed, but not as robustly significant. Attacked E.U. is statistically significant in the two post-2002 models. 
Interestingly, only attacking in Russia is not associated with terrorist designation by this set of countries. This could be because Russia has fewer ties to the other countries, so when it is attacked, they do not respond with designation. This is consistent with the analysis of Ilbiz and Curtis, who argue that Russia is relatively "independent" with its proscription patterns. ${ }^{106}$

Of the control variables based on group attributes, only Group age is consistently associated with terrorist designation by more countries, or any countries. This is consistent with expectations. Older groups get designated by more countries or are more likely to get designated by any country.

The non-results for some control variables are noteworthy. Total deaths (log) is significant in Models 2 and 4, but insignificant in Model 1 and marginally significant in Model 3. It is remarkable that fatalities are not robustly associated with group proscription. This is somewhat comparable to the lack of results for Hypothesis 1 and Hypothesis 2. Designation is not based (only) on organizational violence. Another perhaps surprising finding is that Aviation target is only statistically significant in one model, Model 4. Beck and Miner had found this variable to be associated with U.S. designation, but we do not find a consistent relationship with designation by multiple countries here. ${ }^{107}$ Group size is never statistically significant. Apparently, a larger group membership is not associated with terrorist designation by these countries.

Table 2 shows the models of country-specific lists. One main conclusion that can be drawn is that there is a great deal of heterogeneity across these lists. There is no single independent variable that is statistically significant across all six lists. Regarding hypothesized relationships, Target type is only statistically significant in the Pakistan model. Groups are more likely to be proscribed by Pakistan if they attack civilian targets. The insignificance in other models suggests a lack of support for Hypothesis 1. Attack method is only statistically significant in Model 7, for the E.U. list. Groups are more likely to be designated a terrorist group by the European Union if their attacks were of a "severe" type like bombings, as opposed to less severe methods such as unarmed assaults. Regarding our alternate measure of severity, suicide attacks, this is statistically significant and positively signed in the model for the U.S. list. Groups that carry out suicide attacks are more likely to appear on the U.S. list. There is some support for Hypothesis 1 and Hypothesis 2 on particular country lists, but not generally.

The most robust finding in Table 2 is that of Prior U.S. listing, which is statistically significant in the models of the U.K., E.U., Russian, and Pakistani lists. A group is more likely to be designated as a terrorist group by these four states (or, three states and the European Union) if it previously had been designated by the United States. This suggests substantial support for Hypothesis 3. The findings for Russia and Pakistan are especially noteworthy, given the historical and cultural differences between these two countries and the United States. (The Pakistani finding is probably more understandable because the U.S.-Pakistani partnership in counterterrorism. But the partnership has been complicated. ${ }^{108}$ ) The only country list where previous U.S. designation does not seem to be influential is that of India. This is discussed more below.

Regarding possible policy diffusion effects of other countries, there are substantial correlations among the U.S., U.K., and E.U. lists. This makes sense because of the historic closeness among these countries, including on strategic matters. The variable 
Table 1. Models of terrorist group designation, by up to six possible designators.

\begin{tabular}{|c|c|c|c|c|}
\hline & $\begin{array}{l}\text { Model } 1 \\
\text { All years, count DV } \\
\text { All Countries }\end{array}$ & $\begin{array}{c}\text { Model } 2 \\
\text { 2003-2016, } \\
\text { count DV All Countries }\end{array}$ & $\begin{array}{c}\text { Model } 3 \\
\text { All years, } \\
\text { dummy DV Any Country }\end{array}$ & $\begin{array}{c}\text { Model } 4 \\
2003-2016, \\
\text { dummy DV Any Country }\end{array}$ \\
\hline Target type & $\begin{array}{c}0.100 \\
(0.100)\end{array}$ & $\begin{array}{l}-0.058 \\
(0.114)\end{array}$ & $\begin{array}{c}0.107 \\
(0.105)\end{array}$ & $\begin{array}{l}-0.095 \\
(0.135)\end{array}$ \\
\hline Attack method & $\begin{array}{c}0.145 \\
(0.109)\end{array}$ & $\begin{array}{l}0.217^{*} \\
(0.113)\end{array}$ & $\begin{array}{c}0.147 \\
(0.115)\end{array}$ & $\begin{array}{l}0.223^{*} \\
(0.129)\end{array}$ \\
\hline Suicide attack & $\begin{array}{c}1.593^{* * *} \\
(0.321)\end{array}$ & $\begin{array}{c}0.597 \\
(0.367)\end{array}$ & $\begin{array}{c}1.837^{* * *} \\
(0.329)\end{array}$ & $\begin{array}{l}0.690^{*} \\
(0.372)\end{array}$ \\
\hline Islamist & $\begin{array}{c}0.963^{* * *} \\
(0.319)\end{array}$ & $\begin{array}{c}1.095^{* * *} \\
(0.369)\end{array}$ & $\begin{array}{c}0.859^{* * * *} \\
(0.323)\end{array}$ & $\begin{array}{c}1.001^{* * *} \\
(0.379)\end{array}$ \\
\hline$A Q$ affiliate & $\begin{array}{c}2.372^{* * *} \\
(0.575)\end{array}$ & $\begin{array}{l}1.471^{* *} \\
(0.675)\end{array}$ & $\begin{array}{c}3.616^{* * *} \\
(0.598)\end{array}$ & $\begin{array}{c}2.248^{* * *} \\
(0.738)\end{array}$ \\
\hline IS affiliate & $\begin{array}{c}2.255^{* * *} \\
(0.699)\end{array}$ & $\begin{array}{l}1.506^{* *} \\
(0.706)\end{array}$ & $\begin{array}{c}2.761^{* * *} \\
(0.644)\end{array}$ & $\begin{array}{c}2.191^{* * *} \\
(0.737)\end{array}$ \\
\hline Attacked U.S. & $\begin{array}{c}-2.597^{* * * *} \\
(0.664)\end{array}$ & $\begin{array}{c}-2.541^{* * *} \\
(0.942)\end{array}$ & $\begin{array}{c}-3.013^{* * * *} \\
(0.629)\end{array}$ & $\begin{array}{c}-3.012^{* * * *} \\
(0.777)\end{array}$ \\
\hline Attacked U.K. & $\begin{array}{l}1.240^{* *} \\
(0.558)\end{array}$ & $\begin{array}{c}2.269^{* * * *} \\
(0.717)\end{array}$ & $\begin{array}{c}1.362^{* * *} \\
(0.513)\end{array}$ & $\begin{array}{c}2.876^{* * *} \\
(1.018)\end{array}$ \\
\hline Attacked E.U. & $\begin{array}{c}0.062 \\
(0.477)\end{array}$ & $\begin{array}{c}1.879 * * * \\
(0.458)\end{array}$ & $\begin{array}{l}-0.169 \\
(0.501)\end{array}$ & $\begin{array}{c}2.278^{* * *} \\
(0.712)\end{array}$ \\
\hline Attacked Russia & $\begin{array}{c}0.529 \\
(0.650)\end{array}$ & $\begin{array}{l}-0.287 \\
(0.578)\end{array}$ & $\begin{array}{c}0.493 \\
(0.859)\end{array}$ & $\begin{array}{l}-0.330 \\
(0.717)\end{array}$ \\
\hline Attacked Pakistan & $\begin{array}{l}1.089^{*} \\
(0.582)\end{array}$ & $\begin{array}{l}1.206^{* *} \\
(0.588)\end{array}$ & $\begin{array}{l}1.184^{*} \\
(0.674)\end{array}$ & $\begin{array}{l}1.696^{* *} \\
(0.813)\end{array}$ \\
\hline Attacked India & $\begin{array}{c}1.470^{* * *} \\
(0.276)\end{array}$ & $\begin{array}{c}1.157^{* * *} \\
(0.356)\end{array}$ & $\begin{array}{c}1.770^{* * *} \\
(0.305)\end{array}$ & $\begin{array}{c}1.565^{* * *} \\
(0.393)\end{array}$ \\
\hline Total deaths (log) & $\begin{array}{c}0.039 \\
(0.029)\end{array}$ & $\begin{array}{c}0.094^{* * *} \\
(0.034)\end{array}$ & $\begin{array}{l}0.056^{*} \\
(0.033)\end{array}$ & $\begin{array}{c}0.143^{* * *} \\
(0.037)\end{array}$ \\
\hline Aviation target & $\begin{array}{l}-0.355 \\
(0.232)\end{array}$ & $\begin{array}{l}-0.147 \\
(0.350)\end{array}$ & $\begin{array}{l}-0.175 \\
(0.255)\end{array}$ & $\begin{array}{l}1.025^{* *} \\
(0.449)\end{array}$ \\
\hline Group age & $\begin{array}{c}0.084^{* * *} \\
(0.011)\end{array}$ & $\begin{array}{c}0.046^{* * *} \\
(0.011)\end{array}$ & $\begin{array}{c}0.087^{* * *} \\
(0.012)\end{array}$ & $\begin{array}{c}0.046^{* * *} \\
(0.012)\end{array}$ \\
\hline Group size & $\begin{array}{l}-0.164 \\
(0.147)\end{array}$ & $\begin{array}{l}-0.076 \\
(0.174)\end{array}$ & $\begin{array}{l}-0.211 \\
(0.158)\end{array}$ & $\begin{array}{l}-0.119 \\
(0.207)\end{array}$ \\
\hline Constant & & & $\begin{array}{c}-3.744^{* * *} \\
(0.416)\end{array}$ & $\begin{array}{c}-2.082^{* * *} \\
(0.534)\end{array}$ \\
\hline $\mathrm{N}$ & 6623 & 2555 & 6623 & 2555 \\
\hline
\end{tabular}

Standard errors are clustered by group in parentheses. Models 1 and 2 are ordinal logistic regression, while Models 3 and 4 are logistic regression. The term "countries" is used for brevity, but one of the six possible designators is the European Union.

${ }^{*} p<.10$.

${ }^{* *} p<.05$.

${ }^{* * *} p<.01$.

Prior Russia listing is not significant in any of the models, suggesting Russia's designations are not influential for the other countries. This is intuitive given the relative isolation of Russia compared to these states. Prior Pakistan listing is significant for both the U.S. and U.K. lists, which is likely due to cooperation between Pakistan and the United States in particular. This connection is probably also related to groups operating in Pakistan and Afghanistan.

Interestingly, Prior India listing is only statistically significant in the Pakistani list model. This suggests that when a group is designated by India, it is likely to be designated by Pakistan in the following year. This order of designation is likely because sometimes a Pakistan-based group attacks India (which then designates it), and Pakistan only lists it later because of U.S. pressure to do so. It is remarkable that the relationship does not work both ways - Indian designation does not seem to be explained by prior Pakistani designation (see Model 10). 
Table 2. Models of terrorist group designation, for each specific list.

\begin{tabular}{|c|c|c|c|c|c|c|}
\hline & $\begin{array}{l}\text { Model } 5 \\
\text { U.S. list }\end{array}$ & $\begin{array}{l}\text { Model } 6 \\
\text { U.K. list }\end{array}$ & $\begin{array}{c}\text { Model } 7 \\
\text { E.U. list }\end{array}$ & $\begin{array}{l}\text { Model } 8 \\
\text { Russia list }\end{array}$ & $\begin{array}{c}\text { Model } 9 \\
\text { Pakistan list }\end{array}$ & $\begin{array}{l}\text { Model } 10 \\
\text { India list }\end{array}$ \\
\hline Target type & $\begin{array}{c}0.139 \\
(0.130)\end{array}$ & $\begin{array}{l}-0.035 \\
(0.161)\end{array}$ & $\begin{array}{l}-0.194 \\
(0.156)\end{array}$ & $\begin{array}{l}-0.104 \\
(0.208)\end{array}$ & $\begin{array}{l}0.405^{* *} \\
(0.178)\end{array}$ & $\begin{array}{l}-0.016 \\
(0.219)\end{array}$ \\
\hline Attack method & $\begin{array}{l}-0.054 \\
(0.132)\end{array}$ & $\begin{array}{c}0.050 \\
(0.156)\end{array}$ & $\begin{array}{c}0.479 * * * \\
(0.153)\end{array}$ & $\begin{array}{c}0.084 \\
(0.241)\end{array}$ & $\begin{array}{l}-0.241 \\
(0.208)\end{array}$ & $\begin{array}{c}0.126 \\
(0.254)\end{array}$ \\
\hline Suicide & $\begin{array}{l}0.860^{* * *} \\
(0.374)\end{array}$ & $\begin{array}{c}0.209 \\
(0.436)\end{array}$ & $\begin{array}{l}-0.013 \\
(0.513)\end{array}$ & $\begin{array}{c}0.391 \\
(0.553)\end{array}$ & $\begin{array}{l}-0.047 \\
(0.389)\end{array}$ & $\begin{array}{l}1.156 \\
(0.754)\end{array}$ \\
\hline Prior U.S. listing & & $\begin{array}{c}1.603^{* * *} \\
(0.549)\end{array}$ & $\begin{array}{c}2.906^{* * *} \\
(0.620)\end{array}$ & $\begin{array}{l}1.520^{* *} \\
(0.720)\end{array}$ & $\begin{array}{c}1.923^{* * *} \\
(0.655)\end{array}$ & $\begin{array}{l}-0.147 \\
(0.622)\end{array}$ \\
\hline Islamist & $\begin{array}{c}0.654 \\
(0.522)\end{array}$ & $\begin{array}{c}1.811^{* * *} \\
(0.534)\end{array}$ & $\begin{array}{l}-2.224 \\
(1.433)\end{array}$ & $\begin{array}{l}2.357 \\
(1.504)\end{array}$ & $\begin{array}{l}1.611^{* *} \\
(0.815)\end{array}$ & $\begin{array}{l}0.264 \\
(0.637)\end{array}$ \\
\hline AQ-Related & $\begin{array}{l}1.907^{* *} \\
(0.809)\end{array}$ & $\begin{array}{l}-0.428 \\
(0.872)\end{array}$ & & $\begin{array}{l}1.112 \\
(1.208)\end{array}$ & $\begin{array}{c}-2.937^{* * *} \\
(0.909)\end{array}$ & $\begin{array}{c}5.417^{* * * *} \\
(1.799)\end{array}$ \\
\hline IS-Related & $\begin{array}{c}2.325^{* * *} \\
(0.744)\end{array}$ & $\begin{array}{l}1.461^{* * *} \\
(0.686)\end{array}$ & & $\begin{array}{l}-0.227 \\
(1.138)\end{array}$ & $\begin{array}{l}-1.824 \\
(1.313)\end{array}$ & $\begin{array}{c}3.046 \\
(1.988)\end{array}$ \\
\hline Prior U.K. listing & $\begin{array}{l}1.154^{* *} \\
(0.502)\end{array}$ & & $\begin{array}{c}2.617^{* * *} \\
(0.909)\end{array}$ & $\begin{array}{l}1.082 \\
(0.818)\end{array}$ & $\begin{array}{l}1.328^{* *} \\
(0.669)\end{array}$ & $\begin{array}{l}-0.066 \\
(1.083)\end{array}$ \\
\hline Prior E.U. listing & $\begin{array}{c}2.626^{* * *} \\
(0.548)\end{array}$ & $\begin{array}{c}1.641^{* * *} \\
(0.593)\end{array}$ & & $\begin{array}{l}-0.455 \\
(1.367)\end{array}$ & $\begin{array}{c}0.000 \\
(.)\end{array}$ & $\begin{array}{c}0.309 \\
(0.832)\end{array}$ \\
\hline Prior Russia listing & $\begin{array}{c}1.100 \\
(0.873)\end{array}$ & $\begin{array}{c}0.980 \\
(0.828)\end{array}$ & $\begin{array}{l}-1.242 \\
(1.444)\end{array}$ & & $\begin{array}{c}1.666 \\
(1.166)\end{array}$ & $\begin{array}{l}-0.011 \\
(1.581)\end{array}$ \\
\hline Prior Pakistan listing & $\begin{array}{l}1.243^{*} \\
(0.671)\end{array}$ & $\begin{array}{l}1.928^{* *} \\
(0.940)\end{array}$ & & $\begin{array}{c}0.597 \\
(0.894)\end{array}$ & & $\begin{array}{c}2.236 \\
(1.452)\end{array}$ \\
\hline Prior India listing & $\begin{array}{l}-0.241 \\
(0.543)\end{array}$ & $\begin{array}{c}0.421 \\
(0.567)\end{array}$ & $\begin{array}{l}-0.103 \\
(0.751)\end{array}$ & $\begin{array}{l}-0.141 \\
(0.986)\end{array}$ & $\begin{array}{l}1.768^{* *} \\
(0.701)\end{array}$ & \\
\hline Attacked U.S. & $\begin{array}{c}-1.764^{* *} \\
(0.853)\end{array}$ & & & & & \\
\hline Attacked U.K. & & $\begin{array}{c}3.605^{* * *} \\
(1.072)\end{array}$ & & & & \\
\hline Attacked E.U. & & & $\begin{array}{c}1.311 \\
(0.846)\end{array}$ & & & \\
\hline Attacked Russia & & & & $\begin{array}{l}3.445^{* *} \\
(1.340)\end{array}$ & & \\
\hline Attacked Pakistan & & & & & $\begin{array}{c}3.894^{* * *} \\
(0.771)\end{array}$ & \\
\hline Attacked India & & & & & & $\begin{array}{c}5.456^{* * *} \\
(0.975)\end{array}$ \\
\hline Total deaths (log) & $\begin{array}{c}0.146^{* * *} \\
(0.043)\end{array}$ & $\begin{array}{c}0.061 \\
(0.052)\end{array}$ & $\begin{array}{c}0.000 \\
(0.056)\end{array}$ & $\begin{array}{l}-0.061 \\
(0.087)\end{array}$ & $\begin{array}{l}-0.058 \\
(0.077)\end{array}$ & $\begin{array}{c}0.085 \\
(0.056)\end{array}$ \\
\hline Aviation & $\begin{array}{c}0.662 \\
(0.612)\end{array}$ & $\begin{array}{c}0.193 \\
(0.543)\end{array}$ & $\begin{array}{c}0.310 \\
(0.560)\end{array}$ & $\begin{array}{c}1.285 \\
(1.706)\end{array}$ & $\begin{array}{l}-1.192 \\
(1.149)\end{array}$ & $\begin{array}{l}-0.546 \\
(0.915)\end{array}$ \\
\hline Group age & $\begin{array}{c}0.038^{* * *} \\
(0.014)\end{array}$ & $\begin{array}{c}0.011 \\
(0.017)\end{array}$ & $\begin{array}{c}0.031 \\
(0.021)\end{array}$ & $\begin{array}{c}0.022 \\
(0.026)\end{array}$ & $\begin{array}{c}0.005 \\
(0.034)\end{array}$ & $\begin{array}{l}0.080^{* *} \\
(0.031)\end{array}$ \\
\hline Group size & $\begin{array}{c}-0.421^{*} \\
(0.228)\end{array}$ & $\begin{array}{c}0.020 \\
(0.216)\end{array}$ & $\begin{array}{l}-0.401 \\
(0.290)\end{array}$ & $\begin{array}{c}0.704 \\
(0.557)\end{array}$ & $\begin{array}{c}0.334 \\
(0.348)\end{array}$ & $\begin{array}{c}0.676^{* *} \\
(0.339)\end{array}$ \\
\hline $\mathrm{N}$ & 3537 & 3069 & 2928 & 2555 & 2539 & 4516 \\
\hline
\end{tabular}

Standard errors are clustered by group in parentheses. Constants are suppressed for space reasons. ${ }^{*} p<.10$.

${ }^{* *} p<.05$.

${ }^{* * *} p<.01$.

Regarding Hypothesis 4, Islamist is statistically significant and positively signed for the U.K. and Pakistani lists. These countries are more likely to designate Islamist groups. Concerning Hypothesis 5, AQ-related is positively signed and statistically significant for the U.S. and Indian lists. ${ }^{109}$ These countries are more likely to designate al-Qaeda affiliates than groups that are not affiliates. Surprisingly, the variable has a negative and statistically significant relationship with the Pakistani list. Groups affiliated with al-Qaeda are less likely to be proscribed by Pakistan than groups not affiliated with al-Qaeda. IS-related is positively signed and statistically significant in the models for the U.S. and U.K. lists. Overall, there is some support for Hypothesis 5. 
Of control variables in Table 2, the Attacked [country] variables mostly indicate that groups that attack in a country are likely to be designated as a terrorist by that country. One exception is the United States, with a statistically significant negative sign, consistent with results from Table 1. Again, this is because the United States only designates foreign organizations. Another exception is the European Union, where there is no statistically significant relationship between attacking there and designation. This could be a combination of the European Union often designating foreign groups, and the fact that some E.U.-designated groups are dormant, so they did not implement attacks during the analysis. In comparison, attacking the United Kingdom, Pakistan, Russia, and India, is highly significant, implying that these governments are more likely to designate a group when their country has been attacked by the group in question.

As for the control variables measuring group attributes, Total deaths (log) is only significant for the U.S. model, inconsistent with the general trends in Table 1. Aviation target is never statistically significant. Group age is statistically significant for the United States and India, suggesting that older groups are more likely to get designated by these two countries. Similarly, Group size is significant for the United States and India, but negatively signed for the U.S. model. A larger group membership influences the likelihood of being designated by India, but the United States seems more likely to designate smaller groups.

\section{Conclusion}

This paper sought to explain terrorist group designation by focusing on threat perception, U.S. policy diffusion, and Islamist ideology as determinants. Our central findings are that even though governments claim that threats are the primary purpose of their designation mechanism, terrorist designation does not seem to be generally driven by attack or target severity, or even the use of suicide targeting or total group lethality. In contrast, we find that the designation is often a result of policy diffusion, especially from U.S. listing decisions, providing support for the theory of international policy diffusion. Interestingly, Islamist groups are also much more likely to be listed by any or all governments - even after taking into consideration the al-Qaeda and IS networks. In all, the findings contribute by providing a systematic, comparative, and comprehensive analysis of terrorist designation by six governments.

While most previous work only examines Western governments, we analyze Russia, Pakistan, and India alongside the European Union, United Kingdom, and the United States. The designation process and lists of these three former countries have barely been analyzed previously, especially not in comparison to Western designators. We also contribute by including a wide variety of threats as opposed to single tactics, and by analyzing a possible influence of prior designations of six governments, as well as by using the most updated datasets on terrorist groups.

Our findings also suggest several avenues for future research. First, designation does not appear to be the result of severity levels of target types or attack methods, according to prominent measures. Future research could use other measures of terrorism severity, for instance, the "scale invariance" analyzed by Clauset et al. ${ }^{110}$ Regardless of casualty counts or other quantitative measures, it could also be that attacking a particularly visible or shocking target is likely to be associated with subsequent designation. Second, governments are clearly influenced by one another, indicating that the 
designation process could be politicized. This seems especially likely among Western countries. Future work could examine specific relationships between governments, such as trade or foreign investment ties, or alliance membership, to see what makes designation diffusion more likely. More generally, researchers could try to understand why some countries behave differently in their designation processes - or why some countries have terrorist lists, and others do not at all.

Third, while our work is innovative for studying six countries from a few different regions, future work might analyze other governments, such as China or Turkey. Finally, given our finding that proscription does not seem to be driven only by violence attack or target severity - this raises questions about how threats are constructed. This is consistent with critical analyses of counterterrorism, ${ }^{111}$ and suggests additional work from that perspective is helpful for understanding proscription. Overall, given the importance of these issues, scholars should continue to try to understand the causes and consequences of terrorist designation.

\section{Acknowledgments}

The authors thank Blair Welsh, Federica Genovese, and Maiyoraa Jeyabraba for their helpful comments on previous versions of the manuscript.

\section{Disclosure statement}

No potential conflict of interest was reported by the authors.

\section{ORCID}

Brian J. Phillips (D) http://orcid.org/0000-0002-9812-4030

\section{Notes}

1. Chantal de Jonge Oudraat and Jean-Luc Marret, "The Uses and Abuses of Terrorist Designation Lists," in The Consequences of Counterterrorism, ed. Martha Crenshaw (New York: Russel Sage Foundation, 2010), 94-129.

2. Victor Asal, Luis De La Calle, Michael G. Findley, Joseph Young, "Killing Civilians or Holding Territory? How to Think about Terrorism," International Studies Review 14, no. 3 (2012): 475-97, doi: 10.1111/j.1468-2486.2011.01127.x; Lee Jarvis and Tim Legrand, "Legislating for Otherness: Proscription powers and parliamentary discourse," Review of International Studies 42, no. 3 (2016): 558-74, doi:10.1017/S0260210515000509; Polina Beliakova, Ronit Berger, and Assaf Moghadam, "Say Terrorist, Think Insurgent: Labeling and Analyzing Contemporary Terrorist Actors," Perspectives on Terrorism 8, no. 5 (2014): 2-17, http:// www.jstor.org/stable/26297258.

3. Best, Rebecca H., and Simanti Lahiri. "Hard Choices, Soft Targets: Terror Proscription and Strategic Targeting Decisions of FTO." International Interactions (2021): Ahead of print; Sophie Haspeslagh, "Listing Terrorists': The Impact of Proscription on Third-Party Efforts to Engage Armed Groups in Peace Process - A Practitioner's Perspective," Critical Studies on Terrorism 6, no. 1 (2013): 189-208; Haspeslagh, Sophie. Proscribing Peace: How Listing Armed Groups as Terrorists Hurts Negotiations. Manchester University Press, 2021. Hyeran Jo, Brian J. Phillips, and Joshua Alley, "Can Blacklisting Reduce Terrorist Attacks?, in 
The Power of Global Performance Indicators, ed. Judith G. Kelley and Beth A. Simmons (Cambridge: Cambridge University Press, 2020), 271-99; Brian J. Phillips, "Foreign Terrorist Organization Designation, International Cooperation, and Terrorism," International Interactions. Empirical and Theoretical Research in International Relations 45, no. 2 (2019): 316-43;

4. Colin J. Beck and Emily Miner, "Who Gets Designated a Terrorist and Why?", Social Forces 91 no. 3 (2013): 837-72, doi: 10.1093/sf/sos200; Haspeslagh, "Listing Terrorists"; Jenny Hocking, "Counter-Terrorism and the Criminalisation of Politics: Australia's New Security Powers of Detention, Proscription and Control," Australian Journal of Politics \& History, 49, no. 3 (2003): 355-71, doi: 10.1111/1467-8497.00291; Clive Walker, "They haven't gone away you know'. The Persistence of Proscription and the Problems of Deproscription," Terrorism and Political Violence 30, no. 2 (2018): 236-58, doi: 10.1080/09546553.2018.1432201. For exceptions, see Ilbiz, Ethem, and Benjamin L. Curtis. “Trendsetters, Trend followers, and Individual Players: Obtaining Global Counterterror Actor Types from Proscribed Terror Lists." Studies in Conflict \& Terrorism 38.1 (2015): 39-61; and Zhang, Chi. "The Double-track System of Terrorism Proscription in China." Terrorism and Political Violence 33.3 (2021): 505-526.

5. Beck and Miner, "Who Gets Designated a Terrorist and Why?"

6. To our knowledge, this paper is the first to examine these lists in comparison to each other. The research design section justifies this sample in more detail.

7. Best and Lahiri, "Hard Choices, Soft Targets."

8. Jo, Phillips, and Alley, "Can Blacklisting Reduce Terrorist Attacks?"

9. Phillips, "Foreign Terrorist Organization Designation, International Cooperation, and Terrorism."

10. Haspeslagh, "Listing Terrorists," Legrand, Tim, and Lee Jarvis. "Enemies of the state: Proscription powers and their use in the United Kingdom." British Politics 9.4 (2014): 450-471; Zhang, "The Double-track System of Terrorism Proscription in China."

11. This paper uses "group" and "organization" synonymously.

12. Brian J. Phillips, "What is a Terrorist Group? Conceptual Issues and Empirical Implications," Terrorism and Political Violence 27, no. 2 (2015): 225-42, at 237.

13. Audrey Kurth Cronin, How Terrorism Ends: Understanding the Decline and Demise of Terrorist Campaigns (Oxford: Princeton University Press, 2009); Asal et al., "Killing Civilians or Holding Territory?"

14. Dongfang Hou, Khusrav Gaibulloev, and Todd Sandler, "Introducing Extended Data on Terrorist Groups (EDTG), 1970 to 2016," Journal of Conflict Resolution 64, no. 1 (2019): 199-225; Jones, Seth G., and Martin C. Libicki. How terrorist groups end: Lessons for countering al Qa'ida. Vol. 741. Rand Corporation, 2008; Joshua Tschantret, "The old terrorism: a dataset, 1860-1969," International Interactions, 45, no. 5 (2019): 933-48.

15. Lee Jarvis and Tim Legrand, "The Proscription or Listing of Terrorist Organisations: Understanding, Assessment, and International Comparisons," Terrorism and Political Violence 30, no. 2 (2018): 199-215, doi: 10.1080/09546553.2018.1432199.

16. Ibid.; Walker, “They haven't gone away you know."

17. Zhang, "The Double Track System of Terrorism Proscription in China."

Designating a group as terrorist, for example, could result in the freezing or confiscation of an organizations' property; or in the prevention of an organization to travel across national borders, or use specific forms of transport, or running for political office. See Jarvis and Legrand, "The Proscription or Listing of Terrorist Organisations."

18. We use the following terms interchangeably: "designation", "proscription", and "listing".

19. Hyeran Jo, Brian J. Phillips, and Joshua Alley, "Can Blacklisting Reduce Terrorist Attacks?," in The Power of Global Performance Indicators, ed. Judith G. Kelley and Beth A. Simmons (Cambridge: Cambridge University Press, 2020), 271-99; Brian J. Phillips, "Foreign Terrorist Organization Designation, International Cooperation, and Terrorism," International Interactions. Empirical and Theoretical Research in International Relations 45, no. 2 (2019): 
316-43; Paul R. Pillar, Terrorism and U.S. Foreign Policy, (Washington D.C.: Brookings Institution Press, 2004).

20. Cronin, "The 'FTO List' and Congress."

21. "United Nations Security Council Resolution 1373 (2001)", United Nations Security Council Counter-Terrorism Committee, last modified July 13, 2020, accessed August 22, 2020, https://www.un.org/sc/ctc/resources/databases/recommended-international-practices-code s-and-standards/united-nations-security-council-resolution-1373-2001/; Jarvis and Legrand "The Proscription or Listing of Terrorist Organisations."

22. Ibid.; Phillips "Foreign Terrorist Organization Designation, International Cooperation, and Terrorism."

23. Vicki Sentas, "Terrorist Organization Proscription as Counterinsurgency in the Kurdish Conflict," Terrorism and Political Violence 30, no. 2 (2018): 298-317; Walker, “They haven't gone away you know."'

24. Marieke De Goede, "The Politics of Preemption and the War on Terror in Europe," European Journal of International Relations 14, no. 1 (2008): 161-185, doi: $10.1177 / 1354066107087764$.

25. Craig Forcese and Kent Roach, "Yesterday's Law: Terrorist Group Listing in Canada," Terrorism and Political Violence 30, no. 2 (2018): 259-77, doi: 10.1080/09546553.2018.1432211; Nicola McGarrity and George Williams, "The Proscription of Terrorist Organisations in Australia," Terrorism and Political Violence 30, no. 2 (2018): 216-235, doi: 10.1080/09546553.2018.1432200.

26. Forcese and Roach, "Yesterday's Law," 269; Jarvis and Legrand "The Proscription or Listing of Terrorist Organisations."

27. Beck and Miner, "Who Gets Designated a Terrorist and Why?"

28. Suthaharan Nadarajah, "The Tamil Proscriptions: Identities, Legitimacies, and Situated Practices," Terrorism and Political Violence 30, no. 2 (2018): 278-97.

29. Legrand, Tim. "“More symbolic-more political-than substantive": an interview with James R. Clapper on the US Designation of Foreign Terrorist Organizations." Terrorism and Political Violence 30.2 (2018): 356-372; Shapiro, Julie B. "The Politicization of the Designation of Foreign Terrorist Organizations: The Effect on the Separation of Powers." Cardozo Pub. L. Pol'y \& Ethics J. 6 (2007): 547.

30. Stampnitzky, Lisa. Disciplining Terror: How Experts Invented 'Terrorism'. Cambridge University Press, 2013.

31. Walker, Clive. "“They haven't gone away you know." The Persistence of Proscription and the Problems of Deproscription." Terrorism and political violence 30.2 (2018): 236-258.

32. Zhang, "The Double Track System of Terrorism Proscription in China."

33. Zhang, "The Double Track System of Terrorism Proscription in China," 2.

34. Elspeth Guild, "The Uses and Abuses of Counter-Terrorism Policies in Europe: The Case of the 'Terrorist Lists"' Journal of Common Market Studies 46, no. 1 (2008): 173-93; Suthaharan Nadarajah and Dhananjayan Sriskandarajah, "Liberation Struggle or Terrorism? The Politics of Naming the LTTE," Third World Quarterly 26, no. 1 (2008): 87-100, doi: 10.1080/0143659042000322928; Annamarie Oliverio and Pat Lauderdale, "Terrorism as a Deviance or Social Control: Suggestions for Future Research," International Journal of Comparative Sociology 46, no. 1-2 (2005): 153-69, doi: 10.1177/0020715205054475.

35. Audrey K. Cronin, "The 'FTO List' and Congress: Sanctioning Designated Foreign Terrorist Organizations," in Foreign Terrorist Organizations: History Tactics and Connections, ed. Edward V. Linden (New York: Nova Science Publishers Inc., 2004), 123-35; Oudraat and Marret, "The Uses and Abuses of Terrorist Designation Lists."

36. Angela K. Bourne, "Securitization and the Proscription of Terrorist Organizations in Spain," Terrorism and Political Violence 30, no. 2 (2018): 318-35, doi: 10.1080/09546553.2018.1432218; Tim Legrand, “More Symbolic-More Political-Than Substantive:' An Interview with James R. Clapper on the U.S. Designation of Foreign Terrorist Organizations," Terrorism and Political Violence 30, no. 2 (2018): 356-72, doi: 10.1080/09546553.2018.1432220; Sean 
D. Murphy, "International Law, the U.S., and the Non-military 'War' against Terrorism," European Journal of International Law 14, no. 2 (2003): 347-64, doi: 10.1093/ejil/14.2.347.

37. Bourne, "Securitization and the Proscription of Terrorist Organizations in Spain,"; Forcese and Roach, "Yesterday's Law," Zhang, "The Double Track System of Terrorism Proscription in China."

38. Beck and Miner, "Who Gets Designated a Terrorist and Why?"

39. Turk, "Sociology of Terrorism."

40. Beck and Miner, "Who Gets Designated a Terrorist and Why?", 841.

41. Beck and Miner, "Who Gets Designated a Terrorist and Why?", 841; Steven M. Chermak and Jeffrey Gruenewald, "The Media's Coverage of Domestic Terrorism," Justice Quarterly 24, no. 4 (2007): 428-61; Erin M. Kearns, Allison E. Betus, and Anthony F. Lemieux, "Why Do Some Terrorist Attacks Receive More Media Attention Than Others?," Justice Quarterly 36, no. 6 (2018): 985-1022; Oliverio, “The State of Terror."

42. "UPDATE 1-EU court overturns Tamil Tiger sanctions but maintains asset freeze," Reuters, last modified October 16, 2014, accessed May 23, 2020, https://in.reuters.com/article/ sri-lanka-ltte-eu/update-1-eu-court-overturns-tamil-tiger-sanctions-but-maintains-asset-freezeidINL6N0SB3PZ20141016. The E.U. court overturned the LTTE sanctions later on but maintained the freezing of their assets (Ibid.).

43. Conrad and Greene, "Competition, Differentiation, and the Severity of Terrorist Attacks."

44. Chermak and Gruenewald, "The Media's Coverage of Domestic Terrorism."

45. Walter Enders and Todd Sandler, The Political Economy of Terrorism (Cambridge: Cambridge University Press, 2011), 269-287.

46. Louise Lemyre, Michelle C. Turner, Jennifer E. C. Lee, and Daniel Krewski, "Public Perception of Terrorism Threats and Related Information Sources in Canada: Implications for the Management of Terrorism Risk," Journal of Risk Research 9, no. 7 (2007): 755-74.

47. Conrad and Greene, "Competition, Differentiation, and the Severity of Terrorist Attacks."

48. Chermak and Gruenewald, "The Media's Coverage of Domestic Terrorism."

49. Ibid.

50. Patrick T. Brandt and Todd Sandler, "What Do Transnational Terrorists Target? Has It Changed? Are We Safer?," Journal of Conflict Resolution 54, no. 2 (2010): 214-36; Sara MT Polo, "The Quality of Terrorist Violence: Explaining the Logic of Terrorist Target Choice," Journal of Peace Research 57, no. 2 (2019): 235-50.

51. The term "civilians" here indicates not only non-combatants, but also individuals who are not affiliated with the government.

52. Victor Asal, Mitchell Brown, and Marcus Schulzke, "Kill Them All - Old and Young, Girls and Women and Little Children': An Examination of the Organizational Choice of Targeting Civilians," Political Science Research and Methods 3, no. 3 (2015): 589-607; Brandt and Sandler, "What Do Transnational Terrorists Target?,; Conrad and Greene, "Competition, Differentiation, and the Severity of Terrorist Attacks."

53. Polo, "The Quality of Terrorist Violence: Explaining the Logic of Terrorist Target Choice," 238; Max Abrahams, "Credibility Paradox: Violence as a Double-Edged Sword in International Politics," International Studies Quarterly 57, no. 4 (2013): 660-71, doi: 10.1111/isqu.12098.

54. "Terrorist Designations of Boko Haram and Ansaru," US Department of State, last modified November 13, 2012, accessed May 25, 2020, https://2009-2017.state.gov/r/pa/prs/ ps/2013/11/217509.htm.

55. “Terrorist Groups: Hamas," National Counterterrorism Center, last modified January 2014, accessed May 25, 2020, https://www.dni.gov/nctc/groups/hamas.html.

56. Polo, "The Quality of Terrorist Violence: Explaining the Logic of Terrorist Target Choice." See also Chapin, Ellen. "Targeting Transients: The Strategic Logic for Terrorist Targeting of Internally Displaced Persons." Journal of Global Security Studies 6, no. 4 (2021): 1-25; and Farrell, Megan. "The Logic of Transnational Outbidding: Pledging Allegiance and the Escalation of Violence." Journal of Peace Research 57.3 (2020): 437-451.

57. Conrad and Greene, "Competition, Differentiation, and the Severity of Terrorist Attacks." 
58. Ibid.; Aaron Clauset, Maxwell Young, and Kristian Skrede Gleditsch, "On the Frequency of Severe Terrorist Events," Journal of Conflict Resolution 51, no. 1 (2007): 58-87.

59. Conrad and Greene, "Competition, Differentiation, and the Severity of Terrorist Attacks."

60. Mia Bloom, Dying to Kill: The Allure of Suicide Bombings (New York: Columbia University Press, 2005); Jason Warner, Ellen Chapin, and Hilary Matfess, "Suicide Squads: The Logic of Linked Suicide Bombings," Security Studies 28, no. 1 (2018): 25-57.

61. Mia Bloom, "Female suicide bombers: a global trend," Daedalus 136, no. 1 (2007): 94-102.

62. Beck and Miner, "Who Gets Designated a Terrorist and Why?," 843. Two groups in Turkey that have used terrorism, but not suicide terrorism, and were never designated by other countries include Grey Wolves and Turkish Hezbollah.

63. Clauset, Young, and Gleditsch, "On the Frequency of Severe Terrorist Events."

64. Chris Quillen, "A Historical Analysis of Mass Casualty Bombers," Studies in Conflict and Terrorism 25, no. 5 (2011): 279-92.

65. Clauset, Young, and Gleditsch, "On the Frequency of Severe Terrorist Events," These attacks were directly linked to Al Qaida, which has been perhaps the most frequently designated terrorist group in the world.

66. Chia-yi Lee, "Democracy, Civil Liberties, and Hostage-Taking Terrorism," Journal of Peace Research 50, no. 2 (2013): 235-48.

67. Chermak and Gruenwald, "The Media's Coverage of Domestic Terrorism,"; Kearns, Betus, and Lemieux, "Why Do Some Terrorist Attacks Receive More Media Attention Than Others?"

68. Rachel Briggs, The Kidnapping Business (London: The Foreign Policy Centre, 2001).

69. Elizabeth Baldwin, Sanya Carley, and Sean Nicholson-Crotty, "Why do countries emulate each other's policies? A global study of renewable energy policy diffusion," World Development 120, no. 29-45 (2019).

70. Covadonga Meseguer, "Policy Learning, Policy Diffusion, and the Making of a new Order," The Annals of the American Academy of Political and Social Science 598, no. 1 (2005): 67-82.

71. "Proscribed Terrorist Organizations," United Kingdom Home Office, 2020, https://assets. publishing.service.gov.uk/government/uploads/system/uploads/attachment_data/ file/901434/20200717_Proscription.pdf, 22, at 3.

72. Frank Dobbin, Beth Simmons, and Geoffrey Garret, "The Global Diffusion of Public Policies: Social Construction, Coercion, Competition, or Learning?", Annual Review of Sociology 33, no. 1 (2007): 449-72, doi: 10.1146/annurev.soc.33.090106.142507.

73. Lloyd Gruber, Ruling the world: Power politics and the rise of supranational institutions, (Princeton: Princeton University Press, 2000).

74. Chalmers Johnson, Nemesis: The Last Days of the American Republic (New York: Henry Holt and Company, 2007).

75. “United Nations Security Council Resolution 1373 (2001)," United Nations Security Council Counter-Terrorism Committee, accessed May 14, 2020, https://www.un.org/sc/ctc/resources/databases/recommended-international-practices-codes-and-standards/united-nation s-security-council-resolution-1373-2001/.

76. Jarvis and Legrand, "The Proscription or Listing of Terrorist Organisations." Cronin's early work on the U.S. list argues that an advantage of the list is clearly signaling U.S. views about particular groups to other countries. See Cronin, see "The 'FTO List' and Congress."

77. John Dumbrell, "Working with Allies: The United States, the United Kingdom, and the War on Terror," Politics and Policy 34, no. 2 (2006): 452-72, doi: 10.1111/j.1747-1346.2006.00021.x.

78. Phillips, "Foreign Terrorist Organization Designation."

79. Alexander Cooley and Daniel H. Nexon, How Hegemony Ends. The Unraveling of American Power (New York: Oxford University Press, 2020), 99, 143; Lloyd Gruber, Ruling the World (New Jersey: Princeton University Press, 2000).

80. Ilbiz and Curtis, "Trendsetters, Trend Followers, and Individual Players."

81. See the State Department FTO page, https://www.state.gov/foreign-terrorist-organizations/ 
82. Gehrke, Laurenz. Hundreds of lawmakers call on EU to ban Hezbollah. Politico. July 17, 2020. https://www.politico.eu/article/the-eu-must-ban-hezbollah-lawmakers-warn-i n-transatlantic-unison/

83. Nadarajah, Suthaharan. "The Tamil proscriptions: Identities, legitimacies, and situated practices." Terrorism and Political Violence 30.2 (2018): 278-297.

84. Vijaykumar, Mahamtan. "Which countries helped the Sri Lankan government in the Sri Lankan civilian war 2009?” South Asia Journal. May 15, 2020. http://southasiajournal.net/ which-countries-helped-the-sri-lankan-government-in-the-sri-lankan-civilian-war-2009/

85. Rapoport, David C. "The Four Waves of Rebel Terror and September." Anthropoetics 8.1 (2002). Kristopher K. Robinson, Edward M. Crenshaw, and J. Craig Jenkins "Ideologies of Violence: The Social Origins of Islamist and Leftist Transnational Terrorism." Social Forces 84, no. 4 (2006): 2009-26, doi: 10.1353/sof.2006.0106.

86. Robinson et al. "Ideologies of Violence."

87. Hou, Gaibulloev, and Sandler, "Introducing Extended Data on Terrorist Groups,"; Gary LaFree and Laura Dugan, "Introducing the Global Terrorism Database," Terrorism and Political Violence, 19, no. 2 (2007): 181-204, doi: 10.1080/09546550701246817.

88. Future research could use alternate sources such the ITERATE attack data (although it only includes international attacks), or other group-based data such as REVMOD. See Acosta, Benjamin. "Reconceptualizing resistance organizations and outcomes: Introducing the Revolutionary and Militant Organizations dataset (REVMOD)." Journal of Peace Research 56.5 (2019): 724-734.

89. "Foreign Terrorist Organizations," U.S. Department of State, Bureau of Counterterrorism, last modified March 21, 2021, accessed April 2020, https://www.state.gov/foreign-terrorist-organizations/. We use the FTO list, and not other U.S. designation mechanisms, since we are interested in terrorist organizations, and other U.S. lists include individuals and institutions such as charities or firms. Additionally, the FTO list seems to be the most prominent of the U.S. lists. Finally, the FTO list overlaps substantially with other U.S. lists, such as the Specially Designated Global Terrorist or Specially Designated Nationals lists. For example, one analysis found that $85 \%$ of the people on the Specially Designated Global Terrorist List are members of FTOs. The actual percentage could be higher, as group membership is often secret. See Loertscher, Seth, Daniel Milton, Bryan Price, and Cynthia Loertscher. The Terrorist Lists: An Examination of the U.S. Government's Counterterrorism Designations Efforts. Sept. 24, 2020. Combating Terrorism Center. https:// ctc.usma.edu/the-terrorist-lists-an-examination-of-the-u-s-governments-count erterrorism-designations-efforts/

90. 76 international terrorist organizations are listed under the Terrorism Act 2000, and 14 organizations in Northern Ireland were proscribed under previous legislation. "Proscribed Terrorist Organizations," United Kingdom Home Office, 2020.

91. The persons, groups and entities in this list are subject to both the freezing of funds and other financial assets, as well as enhanced measures related to police and judicial cooperation in criminal matters. See "EU Terrorist List," European Council, last modified July 21, 2020, accessed August 23, 2020, https://www.consilium.europa.eu/en/policies/ fight-against-terrorism/terrorist-list/.

92. Persons and entities designated on this list are subject to enhanced measures related to police and judicial cooperation in criminal matters. The E.U. designation list is reviewed every six months.

93. Even though the European Union maintains two separate lists, which are supposed to distinguish between E.U. and non-E.U. entities, the second list does still include all non-E.U. groups, which is why we use the second list. Despite that, some of the designating governments which are included in our analysis do designate EU-based organizations.

94. "EU Terrorist List," European Council, Council of the European Union.

95. "Russian Federation Organizations designated as terrorist basing on the court judgements," Russian Federation Anti-Terrorism Center, last modified January 2021, accessed April 2020, https://www.eng.cisatc.org/1289/134/160/1269. 
96. "Proscribed Organizations," National Counter Terrorism Authority (NACTA), last modified August 6, 2017, accessed April 2020, https://nacta.gov.pk/proscribed-organizations/.

97. “Banned Organizations," Indian Ministry of Home Affairs, last modified August 20, 2020, accessed April 20, 2020, https://www.mha.gov.in/node/91173.

98. We adapted 198 group-names manually before merging the two datasets.

99. Following Conrad and Greene, we code some attack data as "missing," and therefore it is not assigned a category, if the attack is coded as one of the three following target types: Abortion, Other, or Religious. They argue that the severity categorization of these types is not clear.

100. Conrad and Greene, "Competition, Differentiation, and the Severity of Terrorist Attacks," 553.

101. This variable and Attack method are only correlated at .27, which makes sense because Attack method captures a broader range of types of attacks.

102. “Terrorism Research \& Analysis Consortium (TRAC)," last modified May 2021, accessed July 2020, https://www.trackingterrorism.org/; "Mapping Militant Organizations," Center for International Security and Cooperation (CISAC), Stanford, last modified December 2020, accessed July 2020, FSI | CISAC - CISAC (stanford.edu).

103. If there are more than one perpetrator groups for an attack, then only the first perpetrator group is recorded.

104. We add a trivial value, .01, before taking the logarithm since the logarithm of zero is undefined.

105. Beck and Miner, "Who Gets Designated a Terrorist and Why?"

106. Ilbiz and Curtis, "Trendsetters, Trend Followers, and Individual Players."

107. Beck and Miner, "Who Gets Designated a Terrorist and Why?"

108. Greg Bruno and Jayshree Bajoria, "U.S-Pakistan Military Cooperation," Council on Foreign Relations, last modified October 12, 2010, accessed March 20, 2021, https://www.cfr.org/ backgrounder/us-pakistan-military-cooperation.

109. The AQ and IS measures drop from Model 7, for the European Union, since none of these groups appear on the E.U. list.

110. Clauset, Young, and Gleditsch, "On the Frequency of Severe Terrorist Events."

111. Jackson, Richard. "The Epistemological Crisis of Counterterrorism." Critical Studies on Terrorism 8.1 (2015): 33-54; Jarvis and Legrand, "Legislating for Otherness;" Meier, Anna A. "The Idea of Terror: Institutional Reproduction in Government Responses to Political Violence." International Studies Quarterly 64.3 (2020): 499-509. 